\title{
Analisa Distribusi Curah Hujan Harian Maksimum di Stasiun Pengukur Hujan Terpilih di Wilayah Klaten Periode 2008 - 2018
}

\author{
Analysis of Maximum Daily Rainfall Distribution at Selected Rain Gauging Stations \\ in KLATEN Region in Years 2008 - 2018
}

\author{
Purwanti Sri Pudyastuti, Rizal Ahmad Musthofa \\ Program Studi Teknik Sipil, Fakultas Teknik, Universitas Muhammadiyah Surakarta, \\ J1. A. Yani Pabelan Kartasura Tromol Pos I Surakarta, 57102 Indonesia \\ e-mail: psp237@ums.ac.id
}

\begin{abstract}
ABSTRAK
Data hujan merupakan data penting untuk mendesain beragam bangunan infrastruktur keairan seperti kanal banjir, bendungan, jaringan irigasi, jembatan, tanggul, dan saluran air hujan. Analisis statistik perlu diterapkan dalam analisis data hujan untuk memperkirakan nilai masukan yang relevan dalam perencanaan infrastruktur keairan. Penelitian ini berupa analisis statistik hujan harian maksimum pada periode tahun 2008 - 2018 di beberapa stasiun terpilih di Kabupaten Klaten Jawa Tengah, untuk mengetahui distribusi probabilitas yang sesuai di lokasi penelitian, yaitu di stasiun pengukur hujan Prambanan, Kebonarum, Tulung, Juwiring, dan Trucuk,. Analisis statistik yang dilakukan adalah analisis frekwensi untuk mengetahui distribusi probabilitas yang sesuai pada lokasi penelitian. Dengan menerapkan distribusi probabilitas yang sesuai diharapkan akan diperoleh nilai masukan yang relevan dalam perencanaan infrastruktur keairan di masa yang akan datang. Aplikasi AProb_41 digunakan pada penelitian ini untuk hitungan analisis frekuensi. Pemilihan distribusi probabilitas yang sesuai diuji dengan menggunakan metode metode Chi-Kuadrat dan Smirnov-Kolmogorov. Dari hasil analisis diperoleh kesimpulan bahwa untuk data hujan harian maksimum periode 2008 - 2018 distribusi probabilitas yang sesuai digunakan di stasiun pengukur hujan Prambanan, Kebonarum, Tulung dan Trucuk adalah distribusi probabilitas Log Pearson Tipe III. Sedangkan untuk stasiun pengukur hujan Juwiring yang sesuai adalah distribusi probababilitas Normal.

Kata kunci: analisis frekuensi, AProb_41, distribusi probabilitas, infrastruktur keairan.
\end{abstract}

\begin{abstract}
Rainfall data is very important for designing various water infrastructures such as canals, dam, irrigation system, bridges, embankment, and storm water sewer. Statistical analysis needs to be applied in rainfall data analysis to estimate the relevant input value for designing water infrastructures. This study comprises statistical analysis of daily maximum rainfall data in 2008 - 2018 at selected rain gauging stations in Klaten region, Central Java Province. The aim of this study is to find the relevant distribution probability at selected rain gauging stations, i.e. Prambanan, Kebonarum, Tulung, Juwiring, and Trucuk Frequency analysis was apply in this study to find the best probability distribution for the selected rain gauging stations therefore the input value based on rainfall data would be relevant for designing the water infrastructure in the future. AProb_41 application was utilize in this study for frequency analysis calculation. Chi-Squared and Smirnov-Kolmogorov test were conducted to find the best probability distribution. Based on the analysis, it can be concluded that for rainfall data in 2008 - 2018, the fittest probability distribution at Prambanan, Kebonarum, Tulung, and Trucuk rain gauging stations is Log Pearson Type III, whereas at Juwiring rain gauging station, Normal probability distribution is the fittest.

Key words: AProb_41, frequency analysis, probability distribution, water infrastructure
\end{abstract}

\section{PENDAHULUAN}

Pada awal tahun 2015 tanggul anak sungai Dengkeng yang berlokasi di Kabupaten Klaten jebol akibat hujan deras dan mengakibatkan banjir setinggi $2 \mathrm{~m}$ di beberapa desa di Kabupaten Klaten (Sunaryo, 2015). Selain itu, banjir juga melanda beberapa Kecamatan di Kabupaten Klaten pada tahun 2019 yang diakibatkan oleh hujan lebat (Isnanto, 2019).

Desain bangunan-bangunan keairan seperti bangunan pengendali banjir (seperti tanggul, kanal banjir, dan bendungan), jaringan drainase, jaringan irigasi, dan jembatan memerlukan input nilai yang relevan berdasarkan analisa data hujan. Untuk mendapatkan estimasi input nilai yang relevan dari analisa data hujan, salah satu metode yang paling sering digunakan adalah metode statistik berupa analisa frekuensi (Baghel, dkk, 2019). Analisa frekuensi dilakukan dengan menggunakan distribusi probabilitas seperti distribusi Log Normal, Gumbel, Log Pearson Tipe III, Weibull, dan sebagainya.

Tidak semua distribusi probabilitas yang ada cocok diaplikasikan untuk analisa frekuensi data hujan di suatu daerah aliran sungai. Untuk mendapatkan input nilai yang tepat dalam desain bangunan keairan harus dipilih distribusi probabilitas yang tepat pula. Pemilihan distribusi probabilitas yang tepat dapat diuji dengan menggunakan metode antara lain metode Chi-Kuadrat dan Smirnov-Kolmogorov.
Penelitian ini dilakukan untuk mengetahui distribusi probabilitas yang sesuai untuk beberapa stasiun hujan terpilih di Kabupaten Klaten agar nilai input hasil analisa data hujan untuk desain bangunan keairan seperti tanggul dapat dilakukan dengan tepat. Pada penelitian ini aplikasi AProb_41 yang dikembangkan oleh Dr. Ir. Istiarto dari Prodi Teknik Sipil FT UGM digunakan sebagai alat bantu untuk mempermudah hitungan.

\section{TINJAUAN PUSTAKA DAN TEORI}

\section{Uji Konsistensi Data Hujan}

Uji konsistensi data hujan dilakukan untuk mengetahui apakah data hujan tersebut konsisten atau tidak. Salah satu metode untuk menguji konsistensi data hujan adalah metode RAPS (Rescale Ajuste Partial Sums) seperti dijelaskan oleh Sri Harto (1999).

\section{Analisa Frekuensi}

Untuk mendapatkan nilai besaran debit banjir rencana maupun hujan rencana dalam perencanaan bangunan pengendali banjir diperlukan data debit sungai dan data hujan. Analisa frekuensi merupakan metode statistik untuk menghitung banjir rencana maupun hujan rencana dengan kala 
ulang tertentu untuk keperluan perencanaan bangunan keairan seperti bangunan pengendali banjir. Menurut Pudyastuti dkk (2018), analisa frekuensi untuk data hidrologi dapat dilakukan jika memenuhi syarat tertentu, yaitu :

1) Data harus seragam / homogen, yaitu data berasal dari populasi yang sama (DAS tidak berubah, stasiun pencatat data tidak berpindah lokasi, dll).

2) Data harus independent, yaitu besaran data ekstrem tidak terjadi lebih dari sekali.

3) Data harus representatif, yaitu data mewakili keadaan di masa yang akan datang (tidak ada perubahan akibat campur tangan manusia di masa yang akan datang).

Alam dkk (2018) melakukan analisis frekuensi untuk hujan bulanan maksimum di Bangladesh yang memberikan kesimpulan bahwa di Bangladesh distribusi probabilitas yang paling sesuai adalah distribusi probabilitas GEV (Generalized Extreme Value), Pearson Tipe III dan Log-Pearson Tipe III.

Untuk kondisi di Indonesia, distribusi probabilitas yang sering digunakan dalam analisa frekwensi untuk analisis hidrologi antara lain adalah distribusi normal (sangat jarang dijumpai data hidrologi yang sesuai dengan distribusi normal), distribusi log-normal, distribusi log-Pearson tipe III, distribusi Gumbel (Generalized Extreme Value Distribution Type I).

Menurut Soemarto (1987) terdapat 4 jenis distribusi yang sering digunakan dalam analisis frekuensi data hidrologi di Indonesia, yaitu:

\section{Distribusi Normal}

$X_{T}=\bar{X}+k \cdot s$

dengan:

$X_{T}=$ perkiraan nilai yang diharapkan terjadi dengan periode ulang $\mathrm{T}$ tahunan

$\bar{X}=$ nilai rata-rata hitung variat

$\mathrm{s}=$ deviasi standar nilai variat

$\mathrm{k}=$ faktor frekuensi dari distribusi normal

\section{Distribusi Log Normal}

$$
\log X_{T}=\log \bar{X}+k \cdot s
$$

$$
s=\sqrt{\frac{\sum(\log X-\log \bar{X})^{2}}{n-1}}
$$

Keterangan:

$\log \mathrm{X}_{\mathrm{T}} \quad=$ Nilai variat $\mathrm{X}$ yang diharapkan terjadi pada peluang atau periode ulang satu tahun

$$
\begin{aligned}
& \log \bar{X}=\text { Logaritma rata-rata } \\
& \mathrm{S}=\text { Standart deviasi dari logaritma } \\
& \mathrm{k} \quad=\text { Faktor frekuensi } \\
& \mathrm{n} \quad=\text { Jumlah data }
\end{aligned}
$$

3. Distribusi Log-Pearson Type III

Metode yang dianjurkan dalam pemakaian distribusi Log Pearson Type III adalah dengan mengkonvesikan rangkaian datanya menjadi bentuk logaritmis. Hujan harian maksimum diubah dalam bentuk logaritma.

a. Nilai logaritma rata-rata

$$
\log \bar{X}=\frac{\sum \log X_{i}}{n}
$$

$$
S=\sqrt{\frac{\sum\left(\log X_{i}-\log \bar{X}\right)^{2}}{n-1}}
$$

c. Koefisien kemencengan

$$
C s=\frac{n \sum(\log X-\log \bar{X})^{3}}{(n-1)(n-2) \cdot S^{3}}
$$

d. Logaritma hujan periode ulang $\mathrm{t}$

$$
\log X_{t}=\log \bar{X}+k . s
$$

$$
\begin{array}{cl}
\text { dengan: } & =\text { Koefisein kemencengan } \\
\mathrm{Cs} & \\
\log \bar{X} & =\text { Logaritma rata-rata } \\
\mathrm{X}_{\mathrm{t}} & =\text { Tinggi hujan dengan kala ulang } \mathrm{t} \\
\mathrm{k} & =\text { Faktor frekuensi } \\
\mathrm{S} & \text { = Standart deviasi } \\
\mathrm{n} & \text { = Jumlah data }
\end{array}
$$

4. Distribusi Gumbel

$$
X_{T}=\bar{X}+K_{T} s
$$

dengan:

$\mathrm{X}_{\mathrm{T}}=\quad$ nilai ekstrem untuk kala ulang $\mathrm{T}$

$\bar{X}=$ rata-rata dari $\mathrm{X}$

$\mathrm{s} \quad=\quad$ standard deviasi

$\mathrm{K}_{\mathrm{T}}=$ faktor frekuensi

$K_{T}=-\frac{\sqrt{6}}{\pi}\left\{0,5772+\ln \left[\ln \left(\frac{T}{T-1}\right)\right]\right\}$

$\mathrm{T} \quad=$ kala ulang (return period)

\section{Uji Kesesuaian Distribusi Probabilitas}

Untuk mendapatkan nilai besaran debit banjir rencana maupun hujan rencana dalam perencanaan bangunan pengendali banjir diperlukan data debit sungai dan data hujan. Analisa frekuensi merupakan metode statistik untuk menghitung banjir rencana maupun hujan rencana dengan kala ulang tertentu untuk keperluan perencanaan bangunan keairan seperti bangunan pengendali banjir.

Uji kesesuaian distribusi dilakukan untuk mengetahui apakah jenis distribusi curah hujan yang dipilih dalam perhitungan curah hujan dapat diterima atau ditolak, karena apabila tidak tepat dalam memilih jenis distribusi akan mengakibatkan kesalahan perkiraan (Sri Harto, 1999)

1. Uji Chi-Kuadrat

Uji Chi-Kuadrat digunakan untuk menguji simpangan secara vertical, apakah distribusi yang dipilih dapat diterima atau ditolak. Metode ini menguji penyimpangan distribusi secara matematis kedekatan antara data pengematan dan seluruh bagian garis persamaan teoritisnya

$$
\begin{aligned}
& X^{2}=\sum_{i=1}^{N} \frac{\left(O_{i}-E_{i}\right)^{2}}{E_{i}} \\
& E_{i}=\frac{n}{N} \\
& \mathrm{dk}=\mathrm{K}-(\alpha+1)
\end{aligned}
$$

dengan:

$\mathrm{X}^{2} \quad$ = Nilai Chi-Kuadrat terhitung

$\mathrm{E}_{\mathrm{i}} \quad=$ Frekuensi yang diharapkan sesuai pembagian

b. Nilai standar deviasi

kelasnya 
$\mathrm{O}_{\mathrm{i}} \quad=$ Frekuensi yang diamati pada kelas yang sama

$\mathrm{N} \quad=$ Jumlah sub kelompok

$\mathrm{dk}=$ Derajad kebebasan

$\mathrm{K} \quad=$ Banyaknya kelas

$\alpha \quad=$ jumlah parameter

Pengujian Chi-Kuadrat selanjutnya membandingkan antara chi square yang didapatkan dengan chi kritik. Nilai ChiKuadrat tergantung dari derajad kebebasan (dk) dan tingkat signifikansinya.

\section{Uji Smirnov Kolmogorov}

Uji Smirnov Kolmogorof atau sering disebut uji kesesuaian parametrik digunakan untuk menguji simpangan baku dengan cara horizontal, yaitu mencari selisih simpangan maksimum antara distribusi teoritis dengan distribusi empiris $\left(D_{0}\right)$. Cara melakukan uji Smirnov Kolmogorof sebagai berikut:

1) mengurutkan data dan menentukan peluang masingmasing $(\mathrm{Pe})$

2) menentukan nilai masing-masing peluang teoritis $(\mathrm{Pt})$

3) menentukan nilai selisih terbesar antara peluang pengamatan dan peluang teoritis ( $\Delta$ hit).

4) berdasarkan table nilai kritis (Smirnov Kolmogorof Test) dapat ditentukan $\Delta c r$.

5) apabila nilai $\Delta$ hit $<\Delta c r$, maka distribusi teoritis yang digunakan untuk menentukan persamaan distribusi teoritis tidak dapat diterima.

Tabel 1 di bawah ini adalah nilai peluang teoritis pada uji Smirnov-Kolmogorov.

Tabel 1. Peluang Teoritis Pada Uji Smirnov-Kolmogorov (sumber: Sri Harto, 1999)

\begin{tabular}{|c|c|c|c|c|}
\hline \multirow{2}{*}{$\begin{array}{c}\text { Jumlah data } \\
(\mathrm{n})\end{array}$} & \multicolumn{4}{|c|}{ Derajat Kepercay aan $(\alpha)$} \\
\cline { 2 - 5 } & 0,20 & 0,10 & 0,05 & 0,01 \\
\hline 5 & 0,45 & 0,51 & 0,56 & 0,67 \\
\hline 10 & 0,32 & 0,35 & 0,41 & 0,49 \\
\hline 15 & 0,27 & 0,30 & 0,34 & 0,40 \\
\hline 20 & 0,23 & 0,26 & 0,29 & 0,36 \\
\hline 25 & 0,21 & 0,24 & 0,27 & 0,32 \\
\hline 30 & 0,19 & 0,22 & 0,24 & 0,29 \\
\hline 35 & 0,18 & 0,20 & 0,23 & 0,27 \\
\hline 40 & 0,17 & 0,19 & 0,21 & 0,25 \\
\hline 45 & 0,16 & 0,18 & 0,20 & 0,24 \\
\hline 50 & 0,15 & 0,17 & 0,19 & 0,23 \\
\hline
\end{tabular}

\section{Aplikasi AProb_41}

Aplikasi AProb_41 adalah program yang dikembangkan oleh Dr. Ir. Istiarto dosen Prodi Teknik Sipil FT UGM untuk melakukan analisis probabilitas data hidrologi berupa data hujan atau data debit ekstrem atau yang lebih dikenal dengan analisis frekuensi data hidrologi ekstrem. Aplikasi AProb_41 dapat memplot distribusi probabilitas yang cukup relevan untuk diterapkan di Indonesia, yaitu distribusi probabilitas Gumbel, Log Normal, Log Pearson Tipe III, dan distribusi Normal. Pengujian kesesuaian distribusi probabilitas pada aplikasi AProb_41 menggunakan uji Chi-kuadrat dengan tingkat keyakinan $(1-$ alfa $)=90 \%$ dan uji Smirnov-Kolmogorov dengan tingkat keyakinan alfa $=10 \%$.

Aplikasi AProb_41 memerlukan data masukan berupa file teks yang berekstensi .txt atau file worksheet Excel yang berekstensi .xls atau .xlsx dengan data yang dituliskan dalam satu kolom. Baris pertama dari data berupa teks yang merupakan judul data dan baris berikutnya berisi data scalar (angka) yang akan diplotkan dan digunakan dalam perhitungan analisis frekuensi. Setiap sel data skalar hanya berisi 1 (satu) angka. Gambar di bawah ini adalah contoh tampilan data masukan dalam file Excel.

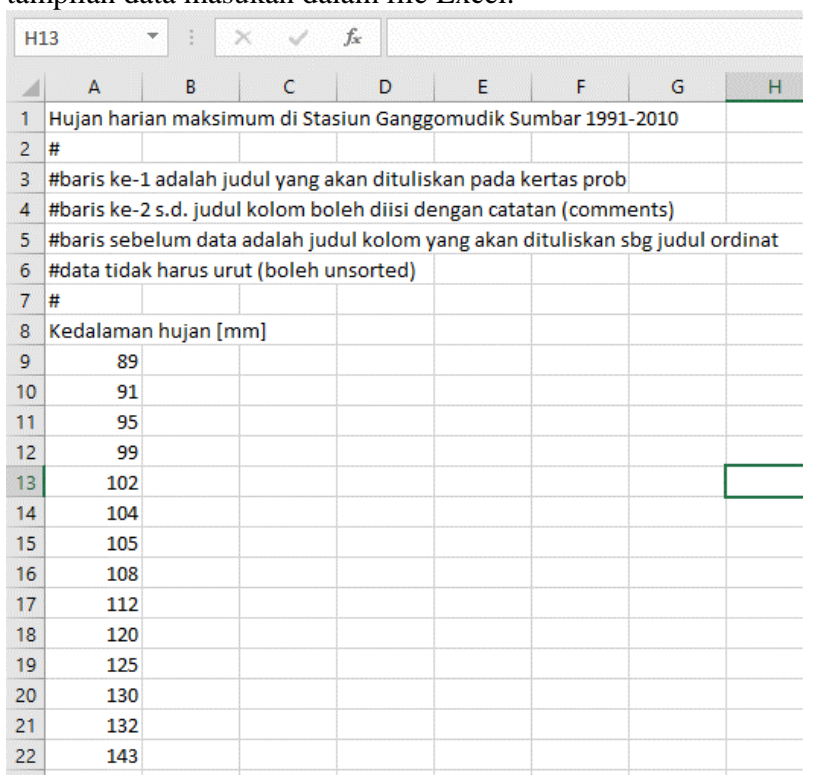

Gambar 1. Contoh Data Masukan untuk AProb_41

Luaran dari aplikasi AProb_41 disimpan dalam 5 file yang terdiri dari ringkasan hasil eksesusi dan plot grafik distribusi probabilitas. Gambar 2 di bawah ini adalah contoh file hasil luaran dari AProb_41.

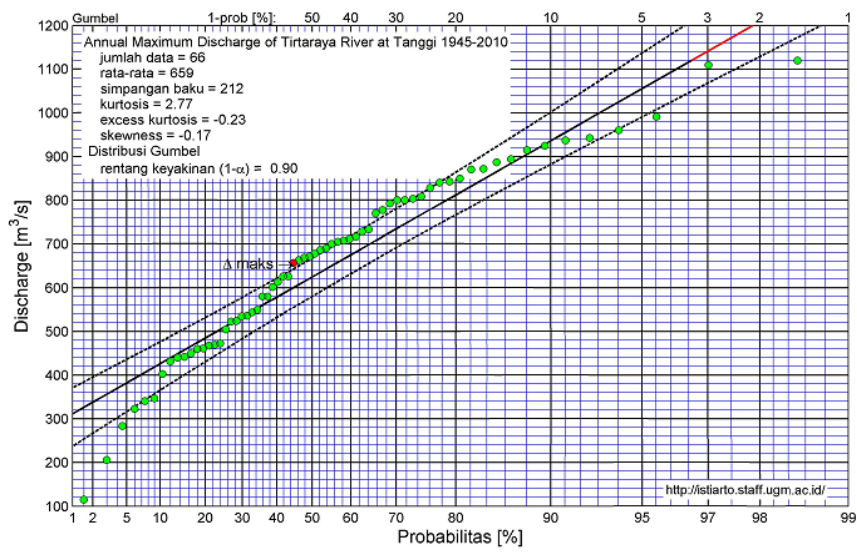

Gambar 2. Contoh Plot Grafik Distribusi Hasil Luaran AProb_41

\section{METODE PENELITIAN}

\section{Lokasi Penelitian}

Lokasi penelitian adalah pada 5 stasiun pengukur hujan terpilih di Klaten, yaitu stasiun Prambanan, Karanganom, Tulung, Juwiring, dan Trucuk. Gambar 3 di bawah ini menunjukkan peta lokasi stasiun pengukur hujan di Klaten. Pada peta yang diperoleh dari Balai Pengelolaan Sumberdaya Air Bengawan Solo terlihat ada banyak stasiun pengukur hujan di Klaten, namun sangat disayangkan tidak semua mencatat data hujan yang lengkap karena banyak stasiun pengukur hujan yang rusak. 


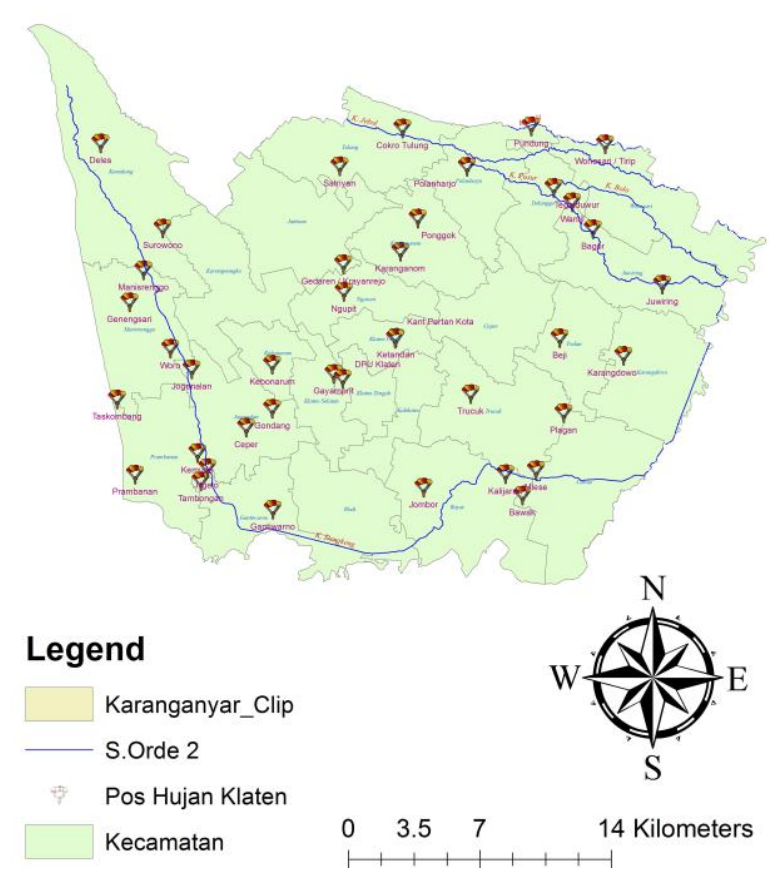

Gambar 3. Lokasi Pos Hujan Pada Penelitian ini (sumber : https://bpusdataru-bs.jatengprov.go.id/index.php?do=klaten)

Pada penelitian ini stasiun pengukur hujan yang dipilih di Kabupaten Klaten ada 5 stasiun, yaitu stasiun Prambanan, Kebonarum, Tulung, Juwiring, dan Trucuk dengan mempertimbangkan kelengkapan data.

\section{Teknik Pengumpulan dan Analisa Data}

Data yang digunakan pada penelitian ini adalah data sekunder yang diperoleh dari instansi terkait, berupa data hujan harian dan peta lokasi stasiun pengukur hujan. Dari data hujan yang tersedia di Balai Sumberdaya Air Bengawan Solo, data yang terlengkap ada di 5 stasiun yaitu stasiun Prambanan, Kebonarum, Tulung, Juwiring, dan Trucuk pada periode tahun $2008-2018$.

Data hujan yang tersedia selanjutnya diolah dan dianalisis. Pengolahan data hujan pada penelitian ini adalah uji konsistensi data hujan dan pengisian data hujan yang hilang. Selanjutnya analisis frekuensi hujan harian maksimum dilakukan dengan menggunakan aplikasi AProb-41. Dari hasil analisis frekuensi akan diperoleh distribusi probabilitas yang paling sesuai untuk statiun pengukur hujan pada penelitian ini.

\section{ANALISA DAN PEMBAHASAN}

\section{Hasil Uji Konsistensi Data Hujan}

Dari hasil uji konsistensi yang dilakukan pada stasiun terpilih dengan menggunakan metode RAPS (Rescaled Adjusted Partial Sum), diperoleh bahwa data hujan pada kelima stasiun terpilih adalah konsisten. Tabel 2 di bawah ini adalah rekap hasil uji konsistensi data hujan pada stasiun terpilih.

Tabel 2. Ringkasan Hasil Uji Konsistensi Data Hujan

\begin{tabular}{|c|c|c|c|c|c|c|c|c|c|c|c|}
\hline \multirow{2}{*}{ No } & \multirow{2}{*}{ StrieH } & \multirow{2}{*}{ Dy } & \multirow{2}{*}{$\mathbf{S t *} \mathbf{k}^{*}$} & \multirow{2}{*}{$\mathbf{S K} \mathbf{K}^{*} \mathbf{M}$} & \multirow{2}{*}{ Q } & \multirow{2}{*}{ R } & \multicolumn{2}{|c|}{ 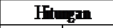 } & \multicolumn{2}{|c|}{ Synt } & \multirow{2}{*}{ Ketarnge } \\
\hline & & & & & & & $Q_{2} \mathbf{n}^{\mathbf{S}}$ & $R \Omega^{45}$ & $04^{15}$ & $\mathbf{R}^{\mathbf{W}}$ & \\
\hline 1 & Pr hing & 493,70 & 2,0531 & 0,0000 & 2,0531 & 2,0531 & 0,6190 & 0,6190 & 1,295 & 1,148 & Konvide \\
\hline 2 & Ketoon-1e & 487,79 & 3,0693 & 0,0000 & 3,0693 & 3,0693 & 0.9254 & 0,9254 & 1,295 & 1,148 & Konside \\
\hline 3 & $T \leftarrow$ & 50932 & 25939 & 0,0000 & 25939 & 25939 & 0,7821 & 0,7821 & 1,295 & 1,148 & Konsiden \\
\hline 4 & Swi- & 533,45 & 1,3624 & 0,0000 & 1,3824 & 1,3824 & 0,4168 & 0,4168 & 1,295 & 1,148 & Konside \\
\hline 5 & Therat & 607228 & 1,437 & 0,0000 & $1,43 \pi$ & 1,4377 & 0,4335 & 0,4335 & 1,295 & 1,148 & Koncide \\
\hline
\end{tabular}

\section{Parameter Statistik Data Hujan}

Pada penelitian ini stasiun pengukur hujan yang dipilih di Kabupaten Klaten ada 5 stasiun, yaitu stasiun Prambanan, Kebonarum, Tulung, Juwiring, dan Trucuk. Stasiun pengukur hujan tersebut dipilih berdasar kelengkapan data hujannya, karena sebagian stasiun yang ada datanya tidak lengkap (kekosongan data pada periode yang terlalu panjang). Data hujan yang digunakan adalah data hujan yang lengkap pada periode tahun 2008 - 2018. Pada stasiun terpilih ada beberapa data yang rusak/kosong, dan data yang rusak tersebut telah diisi dengan metode Reciprocal Method sebelum dilakukan analisis lebih lanjut.

Gambar 4 di bawah ini adalah grafik data hujan harian maksimum di stasiun Prambanan, Kebonarum, Tulung, Juwiring, dan Trucuk.

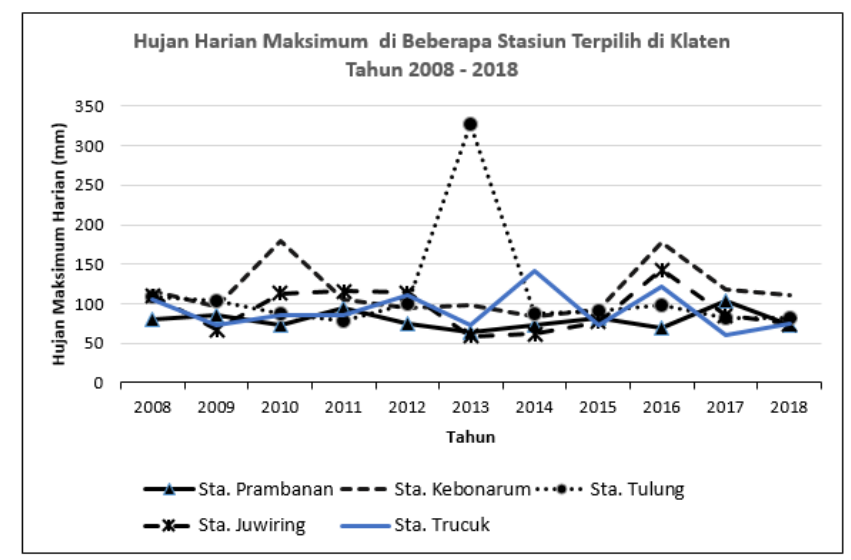

Gambar 4. Hujan Harian Maksimum di Stasiun Terpilih di Klaten Periode $2008-2018$

Hujan harian maksimum tertinggi terjadi di stasiun Tulung yang terjadi pada bulan Desember 2013. Tabel 3 di bawah ini menunjukkan parameter statistik dari data hujan harian maksimum di stasiun terpilih tersebut.

Tabel 3. Parameter Statistik Data Hujan Harian Maksimum Periode 2008 - 2018 di Stasiun Terpilih di Klaten

\begin{tabular}{cccccc}
\hline Parameter Statistik & $\begin{array}{c}\text { Sta. } \\
\text { Prambanan }\end{array}$ & $\begin{array}{c}\text { Sta. } \\
\text { Kebonarum }\end{array}$ & Sta. Tulung & $\begin{array}{c}\text { Sta. } \\
\text { Juwiring }\end{array}$ & Sta. Trucuk \\
\hline Rata-rata & 79.09 & 115.55 & 113.09 & 92.73 & 91.09 \\
Standard deviasi & 11.55 & 33.06 & 71.95 & 27.63 & 25.28 \\
Varians & 133.49 & 1092.87 & 5177.49 & 763.22 & 639.29 \\
Kurtosis & 0.44 & 1.10 & 10.45 & -1.03 & -0.31 \\
Skewness & 0.94 & 1.49 & 3.20 & 0.39 & 0.85 \\
Minimum & 64.00 & 83.00 & 78.00 & 59.00 & 61.00 \\
Maksimum & 103.00 & 180.00 & 328.00 & 143.00 & 141.00 \\
\hline
\end{tabular}

\section{Analisa Frekuensi Hujan Harian Maksimum}

Dari hasil analisis frekuensi dengan menggunakan aplikasi AProb_41 diperoleh luaran seperti tercantum pada Tabel di bawah ini. Distribusi probabilitas yang sesuai di stasiun Prambanan, Kebonarum, Tulung dan Trucuk berdasarkan hasil analisis frekuensi adalah distribusi probabilitas Log-Pearson Tipe III. Sedangkan untuk stasiun pengukur hujan Juwiring, distribusi probabilitas yang sesuai adalah distribusi probabilitas Normal. Tabel 4 di bawah ini menunjukkan ringkasan hasil analisis frekuensi untuk data 
hujan harian maksimum periode 2008 - 2018 di stasiun terpilih di Klaten.

Tabel 4. Ringkasan Analisis Frekuensi

\begin{tabular}{|l|c|c|c|c|c|c|}
\hline Nama Stasiun & $\begin{array}{c}\text { Rerata } \\
\text { Hujan } \\
\text { Harian } \\
\text { Maksimum }\end{array}$ & \multirow{2}{*}{$\begin{array}{c}\text { Standar } \\
\text { Deviasi }\end{array}$} & \multirow{2}{*}{ Skewness } & \multicolumn{2}{|c|}{$\begin{array}{c}\text { Hasil Uji Kesesuaian Distribusi } \\
\text { Probabilitas }\end{array}$} & $\begin{array}{c}\text { Distribusi } \\
\text { Probabilitas } \\
\text { Yang Paling } \\
\text { Sesuai }\end{array}$ \\
\hline Prambanan & 79.09 & 11.55 & 0.94 & $\begin{array}{c}\text { LP III, LN, } \\
\text { Normal }(2,364)\end{array}$ & LP III (0,084) & LP III \\
\hline Kebonarum & 115.55 & 33.06 & 1.49 & $\begin{array}{c}\text { LP III, Gumbel, } \\
\text { LN (3,636) }\end{array}$ & LP III (0,11) & LP III \\
\hline Tulung & 113.09 & 71.95 & 3.2 & Gagal & LP III $(0,135)$ & LP III \\
\hline Juwiring & 92.73 & 27.63 & 0.39 & $\begin{array}{c}\text { LP III, Gumbel, } \\
\text { LN (6,182) }\end{array}$ & Normal $(0,151)$ & Normal \\
\hline Trucuk & 91.09 & 25.28 & 0.85 & $\begin{array}{c}\text { LP III, Gumbel, } \\
\text { LN, Normal } \\
(7,455)\end{array}$ & LP III (0,148) & LP III \\
\hline
\end{tabular}

Keterangan $: L P I I I=L o g-P e a r s o n$ Tipe $I I I ; L N=L o g$ Normal; angka di dalam kurung adalah nilai selisih maksimum dari uji Chi-Kuadrat dan Smirnov-Kolmogorov.

Hasil analisis frekuensi menunjukkan bahwa untuk data hujan harian maksimum periode 2008 - 2018 di stasiun pengukur hujan Tulung di mana nilai standard deviasinya jauh lebih tinggi daripada stasiun yang lain untuk uji Chi-Kuadrat tidak memenuhi syarat untuk keempat distribusi probabilitas yang diuji. Hal ini menunjukkan bahwa nilai standar deviasi berpengaruh dalam uji kesesuaian distribusi probabilitas.

Gambar 5 - 9 di bawah ini menampilkan plot data hujan harian maksimum di stasiun terpilih pada distribusi probabilitas yang paling sesuai untuk masing-masing stasiun.

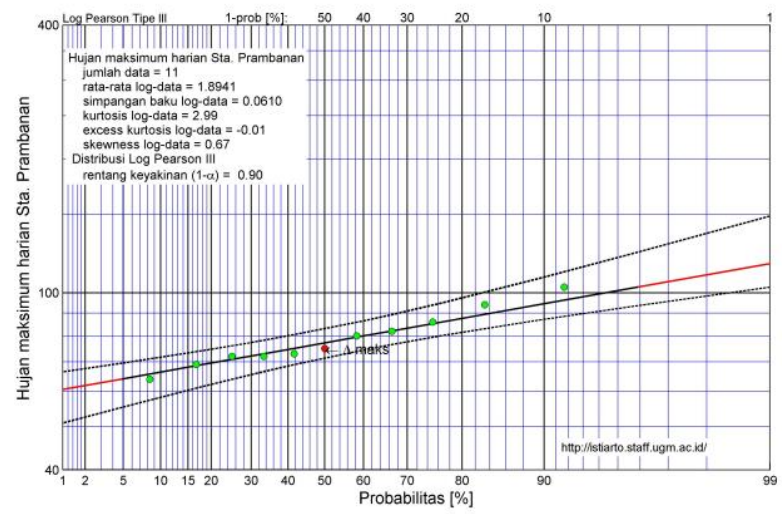

Gambar 5. Plot Distribusi Probabilitas Log-Pearson Tipe III untuk Data Hujan Harian Maksimum Periode 2008 - 2018 di Stasiun Prambanan

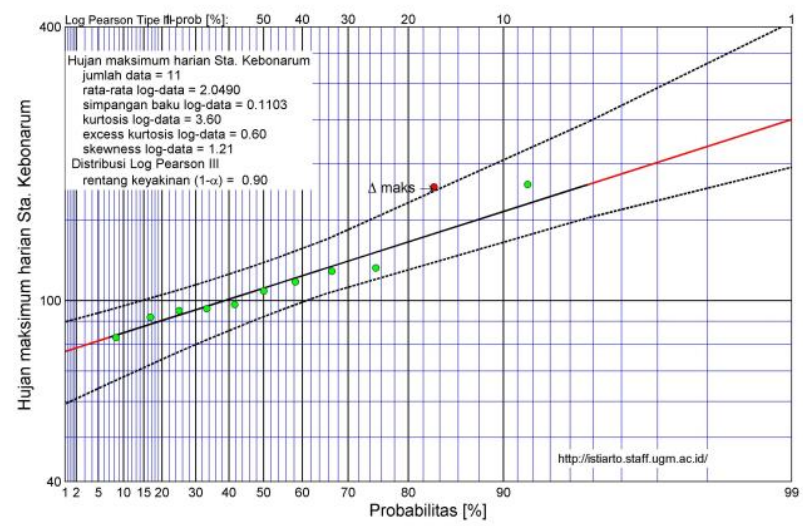

Gambar 6. Plot Distribusi Probabilitas Log-Pearson Tipe III untuk Data Hujan Harian Maksimum Periode 2008 - 2018 di Stasiun Kebonarum

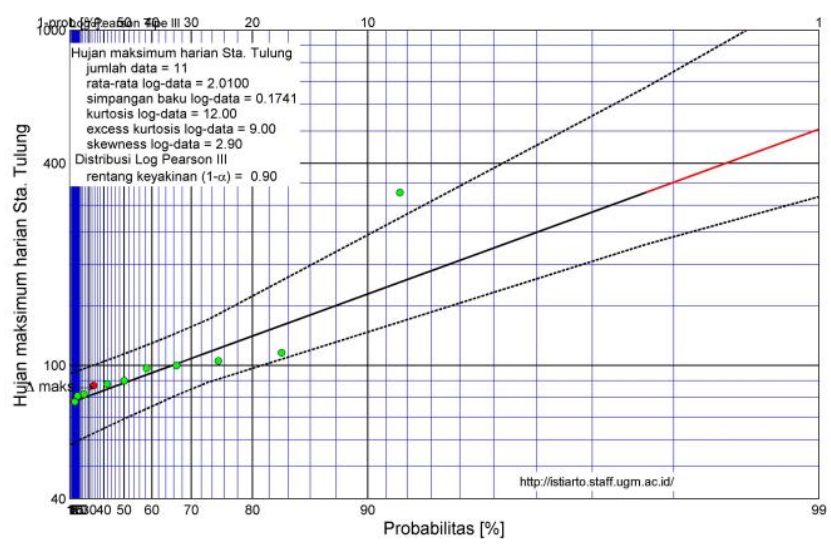

Gambar 7. Plot Distribusi Probabilitas Log-Pearson Tipe III untuk Data Hujan Harian Maksimum Periode 2008 - 2018 di Stasiun Tulung

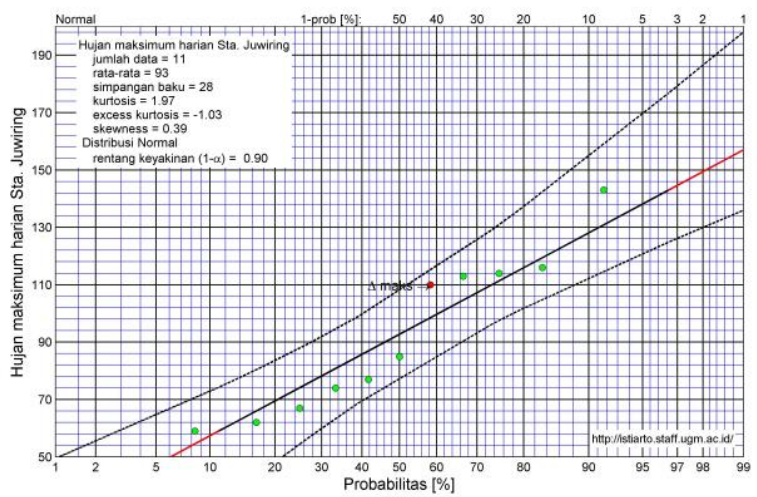

Gambar 8. Plot Distribusi Probabilitas Normal untuk Data Hujan Harian Maksimum Periode 2008 - 2018 di Stasiun Juwiring

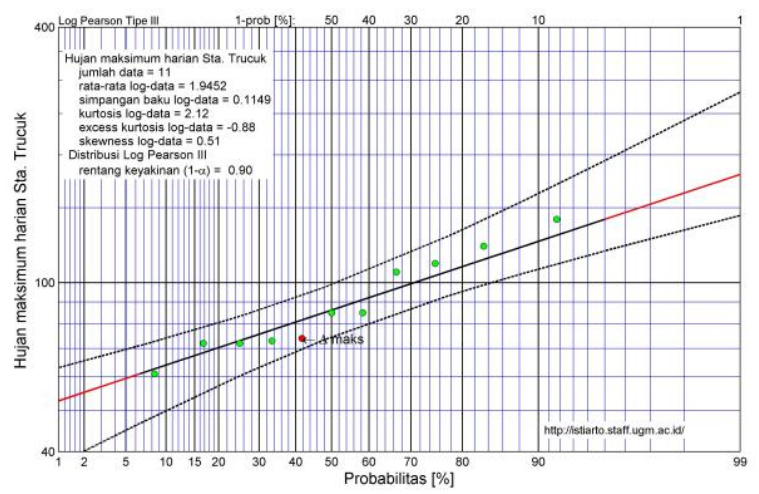

Gambar 9. Plot Distribusi Probabilitas Log-Pearson Tipe III untuk Data Hujan Harian Maksimum Periode 2008 - 2018 di Stasiun Trucuk

Dari plot tersebut dapat dilihat perkiraan besaran hujan harian maksimum pada kala ulang tertentu yang akan bermanfaat untuk perencanaan bangunan keairan seperti saluran drainase, tanggul, dan sebagainya.

\section{KESIMPULAN DAN SARAN}

Berdasarkan analisis pada penelitian ini maka ada beberapa kesimpulan yang dapat diambil, yaitu: 
1. Distribusi probabilitas yang paling sesuai untuk data hujan harian maksimum periode 2008 - 2018 pada stasiun Prambanan, Kebonarum,,Tulung, dan Trucuk adalah distribusi probabilitas Log-Pearson Tipe III.

2. Distribusi probabilitas yang paling sesuai untuk data hujan harian maksimum periode 2008 - 2018 pada stasiun Juwiring adalah distribusi probabilitas Normal.

Untuk hasil yang lebih baik bagi penelitian sejenis selanjutnya, maka ada beberapa saran sebagai berikut:

1. Stasiun hujan yang sudah rusak sebaiknya diganti dengan yang baru agar ketersediaan data hujan di Kabupaten Klaten lebih memadai.

2. Data hujan dengan periode yang lebih panjang akan menghasilkan analisa frekuensi yang lebih akurat. Oleh karena itu ketersediaan data dengan periode yang lebih panjang perlu diperhatikan oleh instansi terkait..

\section{UCAPAN TERIMAKASIH}

Penulis mengucapkan terimakasih kepada Program Studi Teknik Sipil Fakultas Teknik UMS yang telah memberikan dukungan sehingga naskah publikasi ini dapat diwujudkan. Penghargaan setinggi-tingginya juga disampaikan ke Dr. Ir. Istiarto yang telah mengembangkan aplikasi AProb_41 sehingga memudahkan dalam melakukan hitungan analisis frekuensi.

\section{DAFTAR PUSTAKA}

Alam, M.A., Emuro, K., Farnham, C., and Yuan, J. (2018). Best Fit Probability Distributions and Return Periods for Maximum Monthly Rainfall in Bangladesh. Journal Climate, doi: https://doi.org/10.3390/cli6010009

Baghel, H., H.K. Mittal, P.K. Singh, K.K. Yadav and Jain, S. (2019). Frequency Analysis of Rainfall Data Using Probability Distribution Models. Int.J.Curr.Microbiol.App.Sci. $\quad 8(06)$ : 1390-1396.doi: https://doi.org/10.20546/ijcmas.2019.806.168

Balai Pengelolaan Sumberdaya Air Bengawan Solo, https://bpusdatarubs.jatengprov.go.id/index.php?do=klaten

Isnanto, A. (2019). Hujan Lebat, Banjir Rendam Klaten dan Sukoharjo. Artikel di media online Detik News, 07 Maret 2019.

Istiarto (2014). Aplikasi AProb_41 yang dapat diunduh di http://istiarto.staff.ugm.ac.id/

Pudyastuti, P.S., dkk (2017). Rekayasa Irigasi \& Bangunan Air. Muhammadiyah University Press Surakarta, ISBN: 978-602-361-064-8

Sri Harto, Br. (1999). Analisis Hidrologi. Penerbit Gramedia Pustaka Utama, Jakarta

Sumarto, C.D., (1995). Hidrologi Teknik Edisi-2. Penerbit Erlangga. Jakarta

Sunaryo, A. (2015). Hujan Deras, 10 Desa di Klaten Terendam Banjir Hingga 2 Meter. Artikel Surat Kabar Suara Merdeka, 25 April 2015. 